\title{
African Small and Medium Enterprises, Networks, and Manufacturing Performance
}

\author{
Tyler Biggs* \\ The World Bank
}

and

Manju Kedia Shah

The World Bank

\begin{abstract}
This paper examines the role of private support institutions in determining small and medium enterprise (SME) growth and performance in Sub-Saharan Africa (SSA). It finds that SMEs in SSA get around market failures and lack of formal institutions by creating private governance systems in the form of long-term business relationships and tight, ethnically-based, business networks. There are important links between these informal governance institutions and SME performance. Networks raise the performance of "insiders" and, in the sparse business environments of the SSA region, have attendant negative consequences for market participation of "outsiders," such as indigenous-African SMEs. This is indicated through the determinants of access to supplier credit. Policy interventions will be needed to improve the platform for relationbased governance mechanisms and to address the exclusionary effects of tight networks.

World Bank Policy Research Working Paper 3855, February 2006

The Policy Research Working Paper Series disseminates the findings of work in progress to encourage the exchange of ideas about development issues. An objective of the series is to get the findings out quickly, even if the presentations are less than fully polished. The papers carry the names of the authors and should be cited accordingly. The findings, interpretations, and conclusions expressed in this paper are entirely those of the authors. They do not necessarily represent the view of the World Bank, its Executive Directors, or the countries they represent. Policy Research Working Papers are available online at http://econ.worldbank.org.
\end{abstract}

*Corresponding Author: Tyler Biggs, former Manager of the Regional Program on Enterprise Development, The World Bank. 1028 Union Church Road, Mc Lean, VA-22102. Tel: 703-7595376, Fax: 703-759-5376, Email: Tylerbiggs@aol.com

The authors would like to thank Thorsten Beck, Antony Thompson, Gerard Byam, seminar participants at the Conference on Small and Medium Enterprises held at the World Bank, Oct 14-15, 2004, and three anonymous referees for their useful suggestions. Further comments are welcome and may be directed to Tylerbiggs@aol.com, or mshah@mindspring.com. 


\section{Introduction}

Empirical research has shown that the economic success of small and medium enterprises (SMEs) in many countries derives from the degree to which they are able to overcome market and institutional failures by being embedded in private institutional support systems. In some cases, long-term business relationships substitute for weak public institutions. In other cases, private institutional support mechanisms are provided by large firms to SMEs by way of various business linkages, for example through subcontracting networks. In still others, cooperative relations among groups of SMEs, organized in business networks and in associations or local community clusters, perform these functions. Prominent examples of such private orderings can be found in the interfirm relationships and informal credit arrangements in many Asian and Eastern European countries (Mcmillan and Woodruf 2003), as well as in the satellite networks in Japan, industry clusters in Taiwan, and industrial districts in Italy and the United States (Piore and Sabel 1984; Becattini 1990; Brusco 1992).

The evidence that private institutional arrangements facilitate the performance of SMEs in many countries fits a theory of the firm that views the enterprise as a collection of contracts and relationships between its various stakeholders and with other firms involved in related activities (Coase 1937, 1988; Alchian and Demsetz 1972; Williamson 1985). ${ }^{1}$ In this conception of the firm, it is the totality of these contracts and relationships (the firm's “architecture”) that defines the firm and creates its distinctive capabilities.

Distinctive capabilities, in turn, determine the firm's competitive potential (Kay 1993). For each contract and relationship there is a corresponding financial flow - sales revenues, payments to suppliers, wage bill, payments to investors - or a corresponding flow of returns to social capital (or flow of network externalities). The objective of the firm is to put together an architecture of contracts and relationships that maximizes value added. Since all countries face problems of asymmetric information and state law is far from costless in time and money and may even lead to outcomes that are worse then outcomes obtained by private orderings, the value of architecture rests mainly in its

\footnotetext{
${ }^{1}$ This view of the firm has roots in both transaction cost economics, whose chief proponent is Oliver Williamson, and in the concept of the firm as a collection of contracts, proposed first by Alchian and Demsetz.
} 
capacity to assist in overcoming market and government failures and in its capacity to reduce transaction costs. Firms that can establish efficient architectures can more effectively enforce property rights and business contracts, enhance learning, increase flexibly to respond to changing circumstances, and achieve easy and open exchanges of information, thereby enhancing the potential for division of labor among firms and collective action.

Viewed in this theoretical light, the ability of SMEs to develop and sustain a unique set of private institutional arrangements, adapted to the characteristics of their business transactions and to the investment climate they face, is crucial to the nature of their competitive advantage. It follows then that impediments to establishing and sustaining such unique architectures could have negative affects on SME entry and performance. For policymakers and development agencies interested in promoting SME development in poor countries, these propositions have spurred interest in interventions to assist firms in building the architectures (social capital) found in populations of successful SMEs. In Sub-Saharan Africa (SSA), for example, in the wake of policy reforms to stimulate private sector development, efforts have been introduced to build up private support mechanisms for SME development by way of "linkage programs," bringing large firms and small subcontractors together, and by way of “cluster development” initiatives. And, in the financial area, programs have aimed at expanding enterprise networks into SME lending and savings mobilization mechanisms.

Do such programs make sense for countries in Sub-Saharan Africa? Observing that a particular architecture of private institutional arrangements plays a role in SME success is not a clear cut argument for intervening to encourage its development. Other alternatives may be superior - such as strengthening formal market institutions. It may also be that efficient private institutional support mechanisms for SMEs will emerge naturally on their own via market forces. Moreover, if intervention were called for, what types of policies would make sense? Experienced Africa development specialists often point out that decentralized markets in the region are not reaching efficient outcomes because of the form that private institutional arrangements take, that market fragmentation is frequent, and that entry in certain industries is restricted because of the 
activities of business networks. Such incongruities can have substantial implications for what development programs do in this area. A better understanding of the institutions that support market exchange in SSA would seem essential in developing effective policy prescriptions.

To address these questions, we use data and research results from the Regional Program for Enterprise Development (RPED), a program of manufacturing enterprise surveys across the SSA region, conducted by the World Bank in the 1990s. ${ }^{2}$ Among other things, RPED firm-level data can be used to examine the forms of private support institutions found in SSA and to assess how these private orderings shape patterns of market exchange and firm performance. The first section of the paper lays some groundwork with a brief review of the forces driving the formation of private support institutions in the region. We then look at the social capital embodied in these business support institutions and the way this social capital influences firm performance. In the last section, we consider the natural limits private support institutions face in the SSA setting in fostering SME structural transformation and the role for policy and programs.

The paper finds that SMEs in SSA endeavor to get around market failure and the lack of formal institutions protecting property rights and contracts by creating private governance systems in the form of long-term business relationships and networks, as firms do in other parts of the world. But in much of the region, SMEs find it hard even to establish these simple relation-based governance architectures. Economic instability undermines and weakens incentives for long-term, cooperative business relationships and hinders the creation of efficient private institutional arrangements. In this environment tight, ethnically-based, business networks thrive. However, a coordination failure in the indigenous-African manufacturing business community keeps firms from developing network-based governance architectures analogous to those found in ethnic minority communities. It is shown that there are important links between these informal governance institutions and SME performance. Networks raise the performance of "insiders" and, in the sparse business environments of the SSA region, tight networks can

\footnotetext{
${ }^{2}$ For a description of the RPED research program and data see the World Bank website www.worldbank.org/rped.
} 
have attendant negative consequences for market participation of "outsiders," such as indigenous-African SMEs. This is indicated through the determinants of access to supplier credit. In addition to longer-term, cumulative efforts to built up high-quality formal institutions, policy interventions will be needed to improve the platform for relation-based governance mechanisms and to address the exclusionary effects of tight networks.

\section{Markets and Private Support Institutions in Sub-Saharan Africa}

\section{Economic Environment, Institutions, and Transaction Costs}

The RPED surveys provide us with a broad picture of the characteristics of manufacturing firms and the business climate in SSA (Biggs and Srivastava 1996; Bigsten et al 2000a; Fafchamps 2004). Firms are mainly small with few assets and limited access to finance. At the upper end of a largely bi-modal size distribution is a small group of large companies (200 employees or more), with more access to finance (and often significant debt), which do business mainly in sparse local markets. The middle of the size distribution of firms is still relatively empty. Technical and management skills are low on average, and absenteeism and acts of employee pilfering are numerous. Product standardization is relatively low. Businesses operate under conditions of considerable uncertainty. Financial and insurance markets are severely underdeveloped, limiting access to credit and insurance. And market exchange is underpinned by weak public institutions of property rights and contract, poor governance, and poor infrastructure services. These market features combine to increase the uncertainty of business relationships and raise transaction costs of exchange.

Small companies with few assets reduce the efficacy of legal actions. There are few assets to seize in the case of default and transactions are generally too small to justify the time and money involved in formal court actions. Many business deals simply avoid problems by engaging in self-enforcing, cash-on-delivery spot transactions. These kinds of business relationships facilitate exchange in many cases, but if exchange is confined to 
such simple forms of governance, it can be costly in terms of foregone profitable opportunities requiring more complex contracting arrangements.

Transactions that involve complex products and substantial quantities, which often require inter-temporal arrangements, such as ordering in advance, invoicing, and supplier credit, face significant difficulties in SSA. First off, there is the problem of high variation in product quality. Low standardization in production in much of manufacturing - producers are often "job-shop” manufacturers, making one-off products, rather than "assembly-line" producers of standard products - and unevenness in skill levels across firms increase the likelihood of quality variation in production. Moreover, the small number of upstream suppliers in the market for many products means that buyers cannot be confident that competition will have ensured the quality of various suppliers. Such factors compel buyers to perform costly inspections of orders. Second, searching out and trying different suppliers is difficult and costly in the SSA environment where information is limited, communication is difficult, and infrastructure is poor. Third, limited information about businesses and consumers, poor communications, and the fact that many small firms do not have fixed business sites, makes it relatively easy for delinquent clients to renege on their accounts. Vetting clients for supplier credit is thus difficult and offering credit is risky. Consequently, supplier credit and invoicing are reserved for transactions with larger, well-known clients.

Legal and judicial systems in the region are plagued by antiquated laws and procedures, insufficient human and material resources, poor management, and corruption. ${ }^{3}$ These problems have resulted in extensive case backlogs and long delays, high costs, and a public perception of the legal and judicial system as too costly, unworkable, and corrupt for resolution of most commercial disputes. Of course, the sophistication and quality of legal institutions varies somewhat across countries and there are cases in the RPED surveys where businesses have taken legal disputes to court.

\footnotetext{
${ }^{3}$ The Global Competitiveness Report of the World Economic Forum, 2005 ranks the quality of SSA's business environment at the bottom of the heap. Its index of "Quality of National Business Environment," which measures regulatory obstacles and legal obstacles to doing business, ranks the USA 2, India 32, and four countries in SSA we will be examining in this paper Kenya 63, Zambia 73, Zimbabwe 84, and Tanzania 87.
} 
Firms also report using the threat of court action in a few countries to persuade clients to pay. These cases, however, are mostly concentrated in the largest firm size categories of the sample and in a few countries. For all intents and purposes formal contract enforcement mechanisms are not used by the great majority of firms, particularly SMEs.

Finally, the economies of SSA countries are prone to shocks - periodic weatherrelated distress in agriculture, civil strife, terms-of-trade shocks, frequent policy changes and poor policy management, corruption, infrastructure breakdowns and so on. ${ }^{4}$ These jolts to the economic system cause unanticipated changes in prices and transaction costs, shortages in critical inputs, production setbacks, delays in payment by customers and transportation problems, which result in unexpected changes in enterprise cash flows. Given the acute financial positions of most firms in these poor economies, and the underdevelopment of financial and insurance markets, these unanticipated fluctuations in income often render firms unable to pay on time or to deliver promised products to customers. This financial stress transmits further shocks through the market as other producers and suppliers must adjust. In such shock-prone, financially constrained circumstances, firms find it difficult to plan and to predict the behavior of trading partners.

\section{The Formation of Informal, Private Support Institutions}

Firms respond to the market imperfections and inadequate public enforcement of property rights and contracts in SSA by creating architectures of relational contracts that substitute for failed or non-existent formal institutions and economize on search and screening costs. They enter into long-term trading relationships, relying on incentives to cooperate that arise from playing a repeated game, and they share information and provide mutual insurance in networks, fashioning collectivist systems of enforcement based on multilateral reputation mechanisms.

As the formal legal system is unreliable for settling commercial disputes and costs of search and verification are high, firms trust their long-term customers and suppliers to

\footnotetext{
${ }^{4}$ A detailed discussion of this issue is provided in Collier and Gunning (1999).
} 
pay their bills and deliver quality products on the prospect of future business. Trust is built on a history of successful, repeat transactions. The RPED surveys show, for example, that firms generally deal with a single supplier of a particular input on a regular basis (even when they have a choice among sources of supply) and the average length of relationship exceeds seven years (Bigsten et al. 2000a). But, as many economic activities require dealing with different partners at different times and cooperation is more easily sustained in relationships if sanctions for opportunistic behavior come not just from the business partner who has been cheated but also from other firms in the business community, business and community networks are formed to govern transactions. ${ }^{5}$ Selfgovernance in such networks works by sharing information on non-delivery, late payment, and default via a multilateral reputation mechanism, supported by a framework of credible commitment, enforcement, and coordination.

At early stages of industrialization incentives based on repeated interactions work well. The fact that it is difficult to locate alternative business partners in the SSA environment, because there are few firms, because market information is inadequate, and because transportation costs are high, persuades firms to make efforts to maintain their existing relationships. They recognize that they are locked in to some extent with existing business partners because of high search and screening costs. This provides incentives to behave cooperatively - i.e. reduces incentives for opportunism (Kranton 1996; Ramey and Watson 2001). As a consequence, such self-enforcing relational contracts are shown in the RPED surveys to be one of the standard ways for manufacturers, suppliers and clients to do business in the region. A large majority of African manufactures describe their relationships with suppliers and clients as simple long-term business acquaintances (Bigsten et al. 2000a).

But the SSA business environment also has features that work to undermine and weaken repeated-game incentives for cooperative behavior. Self-enforcing transactions, governed through repeated interaction, depend on expectations about the future (Axelrod 1984; McMillan and Woodruff 2003). There are generally short-term gains to be made

\footnotetext{
${ }^{5}$ One could, of course, consider the transactions of a repeated game and the relational contracting thereof a network. Here we define a network to include a broader set of economic functions where members of a business group or "club" share information and informally enforce contracts.
} 
from breaking relational contracts. This follows from the very nature of relation-based governance. Contractor's freedom of action is not restricted by any legal requirement, but by concern for subsequent loss of business, reputation, or trust. For future benefits to be large enough to induce cooperative behavior, the discounted value of expected future profits must be larger than the gains that could be made from reneging on the deal. Two conditions in the SSA business environment negatively influence the value and predictability of future gains from such relationships and make it harder to establish and sustain cooperation. ${ }^{6}$

First, all business relationships involve risks. Generally such risks are known and can be planned for or ways can be found to hedge them. But the shock-prone SSA environment adds an extra element of uncertainty to the equation. Uncertainty makes it more difficult to predict a business partner's gains and undermines the effectiveness of repeated interaction incentives. When conditions are stable, contracts and business relationships have a predictable value. Firms offering credit, for example, know the loan value - it is predictable to the supplier and to the customer - and the amount of credit offered can be set to benefit the supplier when it is repaid. The value of continuing the relationship is thus predictable. Unforeseen shocks change all of this. The value of not making the required payment fluctuates because of the shocks. If the gains from breaking the promise to pay are large enough, then the customer will default. Relational contracts are thus much harder to sustain in shock-prone environments, because it is harder to predict the behavior of the business partner and to value the relationship. In addition, the costs of establishing relational contracts (i.e. costs of building trust) are much higher in shock-prone environments. Shocks induce unforeseen turnover and

\footnotetext{
${ }^{6}$ One of the consequences of the difficult environment for sustaining cooperation in the SSA region is a very low level of subcontracting. A comparison of data from firm-level surveys conducted under the World Bank's Investment Climate Assessment program in China versus countries in the SSA region shows that, in China, 22\% of manufacturing output is produced for other firms. In contrast, only 3\% of manufacturing output is subcontracted in Africa. When we look at the percentage of firms that work as subcontractors, with $10 \%$ or more of their output being subcontracting work, $35 \%$ of firms in China are subcontractors, compared with only about $6 \%$ in the SSA region. China certainly cannot be held up as the best contracting environment in the world, but its relative economic and political stability does provide a superior platform for relation-based governance of cooperative business transactions.
} 
changes in enterprise control often destroying relationships in their wake. This forces firms to bear the costs of rebuilding trust relationships and architectures more frequently.

Second, in conditions where financial markets are underdeveloped and access to credit is limited the opportunity cost of capital is high and firms have an incentive to take profits today rather than wait for profits tomorrow. Firms have a high discount rate on the future. Poverty and culture (e.g. family and community-based risk-pooling) reinforce such inducements to take current profits and tend to undermine the value of future gains from business relationships, making it harder to establish and sustain cooperation.

Weakened incentives for cooperation, together with extraordinarily high costs of searching, screening, and deterring opportunism in SSA, increase the importance of business networks for market exchange. In these circumstances, there is an added need for the information and collectivist system of enforcement that a network can provide to help make and sustain relational contracts. This is especially true for labor, credit, and other factor market transactions, which are even more susceptible to opportunistic behavior than product market transactions. Given the importance of relation-based governance of business transactions in the region, features that make it harder to establish and sustain cooperative relationships in factor markets create barriers to efficiency and growth. In helping to improve the possibilities for relational contracting, business networks play a supporting role in market development and enhance firm performance.

The RPED surveys allow us to examine the importance of networks in SSA in some detail. In the next section, we look at the effects of networks on SME performance and consider the consequences of the forms that networks take for entry, efficiency, and growth. 


\section{The Power of the Network and Firm Performance}

In the presence of economic instability, market imperfections, and weak government-provided legal institutions, the power of the African business network rests partly on the exchange of information through it and on group enforcement, and partly on the ready ability of the group to support transactions that benefit from relation-based governance, such as financing, sales, and distribution to customers outside the immediate neighborhood. Evidence of such network externalities (or social capital) in SSA has been provided by Barr (2000), Fafchamps (2000, 2004), Biggs, Raturi and Srivastava (2003), and Fisman $(2001,2002)$.

Community connections play a crucial role in the membership of African business networks. The RPED surveys show that ethnicity is a strong indicator of network activity in manufacturing. Ethnic minority groups, for example, dominate many of the major manufacturing activities. In East Africa, for example, business networks of Indian ethnicity concentrate in segments of light manufacturing and import/export trade. In Southern Africa, European business networks control much of the upstream activities in manufacturing and mining. And in West Africa, Lebanese business networks are heavily involved in import/export trade and parts of the wood industry. Across the region indigenous-African, ethnically-based networks are found mainly in agricultural and natural resource activities - the Luo, in Kenya, are networked in the fishing industry and the Ashanti, in Ghana, in the cocoa industry. African ethnically-based networks can also be found in small-scale industrial activities, such as metal working, furniture, food processing and clothing. Fafchamps (2004) argues that the distinct patterns of ethnic concentration in business, observed across SSA, can be explained to a great degree by a restricted entry process in business networks and by network externalities. Since network externalities bestow comparative advantages in business on network members, important ethnic communities earn rents and become dominant in particular segments of the economy. Networks reinforce themselves through a referral process and statistical discrimination. 
To examine the activities of these ethnically-based business networks and see how network externalities confer advantages on members of the group, we focus on a subset of the RPED sample that includes entrepreneur-owned firms, as these firms constitute the SMEs in our sample. Four countries provide the backdrop for the investigation - Kenya, Tanzania, Zambia and Zimbabwe. It was in these countries that the surveys gathered data on ethnic business networks.

\section{Estimates of the Effect of Network Externalities on SME Performance}

How might networks affect enterprise performance? In circumstances where there is a high degree of economic uncertainty, market imperfections are endemic, and formal legal institutions are weak, networks could aid entrepreneurs in entering the market. Members of a network, for example, might be expected to start larger firms, because the network provides connections and credible multilateral enforcement capabilities that facilitate access to supplier credit and other inputs, aid the flow of information on technologies and markets, or ease access to equity investments. Similarly, a network's impact on enterprise productivity or growth could be significant where there are information barriers and credit constraints and firms have difficulty enforcing property rights and business contracts. Networks could provide positive externalities that help firms to overcome such problems, improving value added and growth prospects. Where problems of asymmetric information and enforcement are less important one would expect the value of network externalities to be smaller. But, as we know from the literature, relation-based governance via stable and cohesive networks can be found even in advanced countries with well-developed information and legal infrastructures (see for example Bernstein 1992). These issues are examined here.

Tables 1 through 3 present descriptive statistics that are used in the analysis. Table 1 describes the ethnic distribution of firms in the RPED sample. It shows that the majority of SMEs in manufacturing in Tanzania and Zambia are indigenous-African owned, while in Kenya and Zimbabwe minority ethnic groups are more important: Indian-Asians dominate in Kenya, and represent a significant share of ownership in the other three countries, and Europeans are the most important entrepreneurial group 
(although not by much) in Zimbabwe. ${ }^{7}$ In all the countries, networks of ethnic minority firms produce a large share of value added in manufacturing and control a large share of the upstream supplier industries.

Table 1: Ethnic Distribution of SMEs (percent of firms)

\begin{tabular}{l|cccc}
\hline & Kenya & Tanzania & Zambia & Zimbabwe \\
\hline African & 39 & 73 & 61 & 40 \\
Asian & 60 & 25 & 26 & 16 \\
European & 0.5 & 0.0 & 11 & 41 \\
Other & 0.5 & 2 & 2 & 3 \\
No. of firms & 184 & 158 & 159 & 132 \\
\hline
\end{tabular}

Source: Enterprise Surveys, 1990s. Regional Program on Enterprise Development, World Bank

Tables 2 and 3 present the financial characteristics of SMEs in our sample. We see that a large percentage of SMEs receive supplier credit in Zimbabwe compared with the other countries. This is explained by the deeper financial system and more highly developed manufacturing sector in Zimbabwe in the 1990s. SMEs in Kenya have relatively more access to bank finance than in the other countries - 25 percent of SMEs received at least some bank credit to start their firms, compared with 8 to 11 percent elsewhere. However, as table 3 shows, these characteristics differ significantly across ethnic groups. In all countries, minorities have much greater access to finance and longer relationship with their suppliers compared to indigenous African entrepreneurs; Tanzania is the only country where these differences are not significant, except for title to property.

Table 2: Finance Characteristics of SMEs

\begin{tabular}{lcccc}
\hline & Kenya & Tanzania & Zambia & Zimbabwe \\
\hline $\begin{array}{l}\text { Pct. receiving } \\
\begin{array}{l}\text { Supplier Credit } \\
\text { Avg. years of }\end{array}\end{array}$ & 30.3 & 11.8 & 19.2 & 66.4 \\
$\begin{array}{l}\text { supplier relation } \\
\begin{array}{l}\text { Pct with title to } \\
\text { property }\end{array}\end{array}$ & 8.5 & 7.9 & 8.6 & 12.0 \\
$\begin{array}{l}\text { Pct. rec. any bank } \\
\text { loan at startup }\end{array}$ & 37.4 & 37.1 & 47.9 & 43.2 \\
\hline Source: En & 24.6 & 8.2 & 11.4 & 11.2 \\
\hline
\end{tabular}

Source: Enterprise Surveys 1990s, Regional Program on Enterprise Development, World Bank

\footnotetext{
${ }^{7}$ It should be noted that the RPED sample was drawn on the basis of employment rather than on the basis of the number of firms.
} 
Table 3: Finance Characteristics of SMEs, by Ethnicity

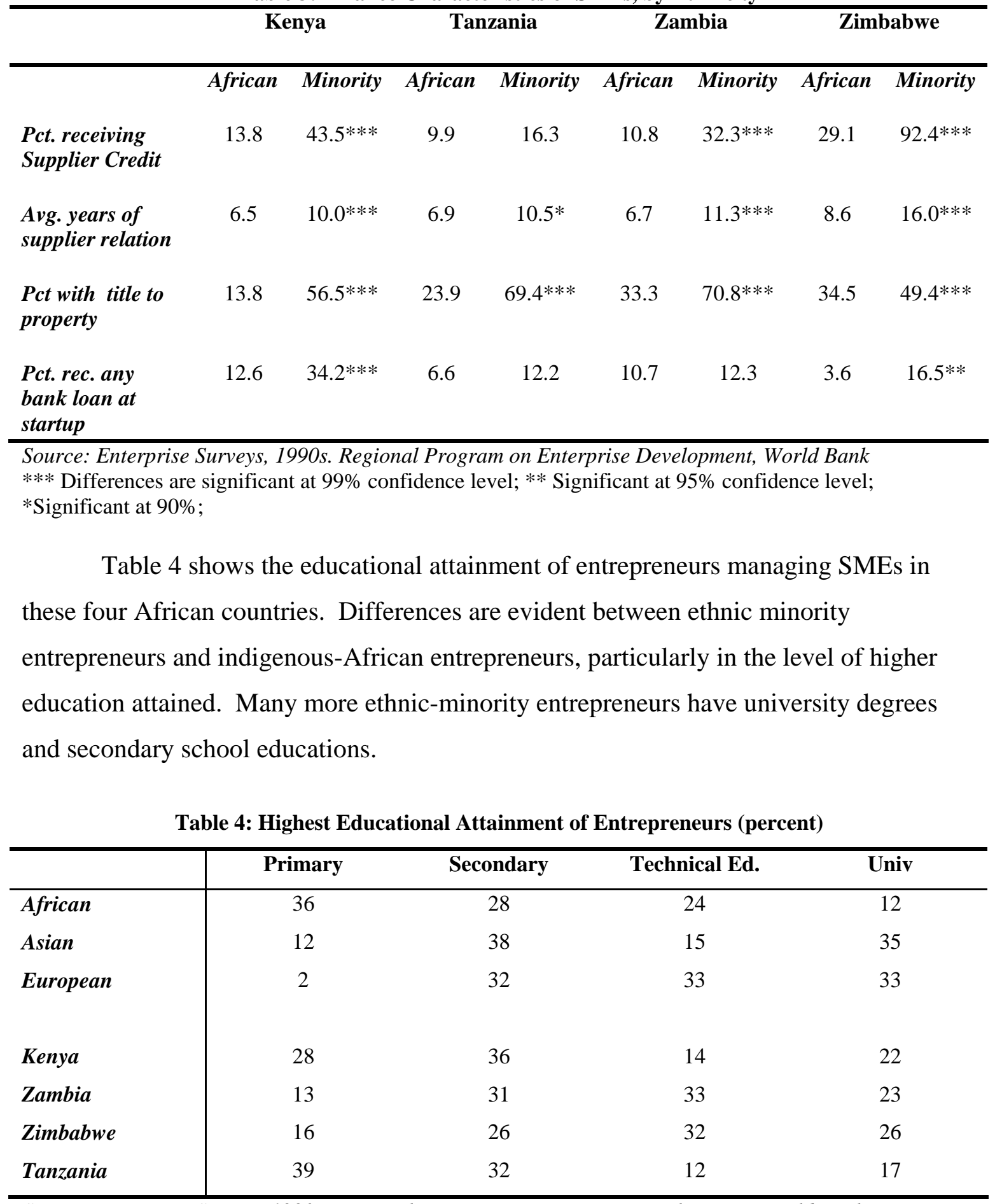

Source: Enterprise Surveys 1990s, Regional Program on Enterprise Development, World Bank 


\section{Networks and SME Entry}

Table 5 presents the results of a regression analysis that examines the power of the ethnic network in determining firm size at start up. Size at entry is important because it is a predictor of future prospects, such as survival and ability to grow in the SSA environment (Biggs and Shah 2002). The hypothesis is that members of a network are able to start larger firms, because the network provides connections, information, and governance capabilities, which facilitate access to credit and other inputs, access to technologies and markets, or access to equity investments.

We examine first the effect on size at start-up of belonging to a minority ethnic network without controlling for other possible determinants of size at start. Model I looks at whether networked entrepreneurs start firms in a different size class compared with indigenous-African firms. We know from the RPED surveys that indigenousAfrican SMEs in manufacturing in these countries lack the strong business networks enjoyed by ethnic minority entrepreneurs (Biggs and Srivastava 1996; Fafchamps 2004). In particular, they lack effective multilateral reputation mechanisms able to share information on payment histories and enforce contracts through group sanctions. The results of model I confirm that the coefficients for Asian and European networked firms are highly significant and positive, indicating that firms belonging to these stable and cohesive business groups start at twice the size of indigenous-African firms.

But this result could be influenced by other factors, such as education of the entrepreneurs, their initial assets or their access to start-up finance. Model II controls for human capital. The results demonstrate that educational attainment matters. Entrepreneurs with university or technical degrees start bigger firms. The coefficient for university education, for example, suggests that entrepreneurs with a university degree start firms approximately 50 percent larger than entrepreneurs with only primary education. Nevertheless the network coefficient remains positive and highly significant 
indicating that the power of the network is still evident even after controlling for the effects of human capital.

If finance constrains size at start up, then entrepreneurs with larger assets and access to finance could be expected to start larger firms. When we control for the entrepreneur's financial position at start-up in model III, the results show that firms with more collateralizable assets, such as title to property, start bigger firms, as do firms with access to bank loans. Informal loans, on the other hand, appear to be insignificant in determining startup size. But controlling for assets and access to finance does not diminish the effect of network externalities. The network coefficients are reduced somewhat, but they still remain large and significant. So, while attributes of entrepreneurs, such as education and training and access to finance, play an important role, it is clear that being a member of a stable and cohesive business network is a key determinant of size at entry in SSA. 
Table 5: Determinants of Startup Size: regression results ${ }^{8}$

\begin{tabular}{|c|c|c|c|}
\hline & Model 1 & Model II & Model III \\
\hline Intercept & $\begin{array}{l}0.25 \\
(0.66)\end{array}$ & $\begin{array}{l}0.06 \\
(0.66)\end{array}$ & $\begin{array}{l}0.24 \\
(0.63)\end{array}$ \\
\hline Log(agest) & $\begin{array}{l}0.31^{*} \\
(0.18)\end{array}$ & $\begin{array}{l}0.32 * \\
(0.18)\end{array}$ & $\begin{array}{l}0.23 \\
(0.17)\end{array}$ \\
\hline Secondary & & $\begin{array}{l}0.05 \\
(0.12)\end{array}$ & $\begin{array}{l}0.06 \\
(0.12)\end{array}$ \\
\hline University & & $\begin{array}{l}0.56 * * * \\
(0.15)\end{array}$ & $\begin{array}{l}0.43^{* * *} \\
(0.15)\end{array}$ \\
\hline Tech.Ed. & & $\begin{array}{l}0.26 * * \\
(0.13)\end{array}$ & $\begin{array}{l}0.25 * * \\
(0.13)\end{array}$ \\
\hline Informal Loan & & & $\begin{array}{l}-0.11 \\
(0.18)\end{array}$ \\
\hline Bank Loan & & & $\begin{array}{l}0.56^{* * *} \\
(0.14)\end{array}$ \\
\hline Title & & & $\begin{array}{l}0.54^{* * *} \\
(0.11)\end{array}$ \\
\hline Asian network & $\begin{array}{l}1.33 * * * \\
(0.12)\end{array}$ & $\begin{array}{l}1.25^{* * * *} \\
(0.12)\end{array}$ & $\begin{array}{l}0.99 * * * \\
(0.13)\end{array}$ \\
\hline European network & $\begin{array}{l}1.03^{* * *} \\
(0.19)\end{array}$ & $\begin{array}{l}0.99 * * * \\
(0.18)\end{array}$ & $\begin{array}{l}0.89 * * * \\
(0.18)\end{array}$ \\
\hline Food & $\begin{array}{l}0.15 \\
(0.16)\end{array}$ & $\begin{array}{l}0.10 \\
(0.15)\end{array}$ & $\begin{array}{l}0.001 \\
(0.15)\end{array}$ \\
\hline Wood & $\begin{array}{l}-0.01 \\
(0.14)\end{array}$ & $\begin{array}{l}-0.01 \\
(0.14)\end{array}$ & $\begin{array}{l}0.006 \\
(0.13)\end{array}$ \\
\hline Metal & $\begin{array}{l}-0.11 \\
(0.15)\end{array}$ & $\begin{array}{l}-0.15 \\
(0.15)\end{array}$ & $\begin{array}{l}-0.15 \\
(0.14)\end{array}$ \\
\hline Kenya & $\begin{array}{l}-0.22 \\
(0.17)\end{array}$ & $\begin{array}{l}-0.17 \\
(0.17)\end{array}$ & $\begin{array}{l}-0.23 \\
(0.17)\end{array}$ \\
\hline Zambia & $\begin{array}{l}0.24 \\
(0.17)\end{array}$ & $\begin{array}{l}0.22 \\
(0.16)\end{array}$ & $\begin{array}{l}0.15 \\
(0.16)\end{array}$ \\
\hline Tanzania & $\begin{array}{l}0.23 \\
(0.17)\end{array}$ & $\begin{array}{l}0.31^{*} \\
(0.17)\end{array}$ & $\begin{array}{l}0.30^{*} \\
(0.16)\end{array}$ \\
\hline Adj. Rsq & 0.22 & 0.25 & 0.31 \\
\hline $\mathbf{N}$ & 472 & 472 & 472 \\
\hline
\end{tabular}

*** Significant at $99 \%$ confidence level; ** Significant at $95 \%$ confidence level; *Significant at $90 \%$;

8 In the regressions, size at start is defined by log of the number of employees at start up. The explanatory variables are defined as follows:

Lagest: is log of the entrepreneur's age when he/she started the firm Secdary: dummy, $=1$ if entrepreneur has secondary school education Univ: dummy, $=1$ if entrepreneur has university degree

Teched: dummy, $=1$ if entrepreneur has vocational/technical degree

Inf. Loan: dummy, $=1$ if entrepreneur obtained loans from friends and family, or supplier credit, for startup

Bank Loan: $=1$ if firm obtained formal loan for startup

Title: $=1$ if entrepreneur has ownership rights on business property

Asian Network: dummy variable, $=1$ if entrepreneur is Asian

European Network: dummy variable, $=1$ if entrepreneur is European

The models also include dummy variables controlling for sector and country differences. 


\section{Networks and SME Productivity}

The set of relational contracts that make up the architecture of the firm shapes the firm's distinctive capabilities and its competitive potential, as we noted earlier. For each relational contract there is a corresponding financial flow or flow of network externalities. Firms try to put together an architecture of relationships that maximizes value added. In table 6, we examine the contribution of network externalities to enterprise productivity. In the context of pervasive market and government failures, networks are hypothesized to raise productivity because network externalities improve access to finance and other inputs, facilitate the flow of information on technology and markets, and enhance coordination of business activities and governance of business contracts.

The analysis uses an augmented Cobb-Douglas production function, where human capital, financial capital, and networking variables are included as added explanatory variables. The left hand side measures log of value added. The explanatory variables include: capital, log of replacement cost of capital; a measure of capacity utilization; labor, log of total workers; education; sector and country dummies; a dummy variable for access to supplier credit; and mean years of relationship with the supplier of the main input.

We control for the education of managers in the production function as it is conjectured that more educated managers deal with the day to day complexities of running a firm more efficiently, and perhaps find, decode, and deploy technologies more effectively than less educated managers. Including finance in the equation is more controversial, as it is difficult to determine the direction of causation. Our hypothesis is that finance - specifically working capital finance in the form of supplier credit influences the firm's day-to-day production capabilities in credit-constrained conditions, such as those found in SSA. There is empirical evidence to warrant such a hypothesis. Fisman (2001) has shown that African firms lacking credit are more likely to face inventory shortages, leading to lower rates of capacity utilization and lower productivity. We also include length of relationship with supplier to control for the fact that firms with 
long-term relationships with suppliers get better access to supplier credit and access to critical raw materials in times of shortages. In addition, access to supplier credit is facilitated by the multilateral reputation mechanism of the business network. To the degree that access to supplier credit is an important network externality one would expect the coefficient of the ethnic network variables to become insignificant when supplier credit is included.

The results show that networked SMEs have significantly higher productivity. For example firms in the Asian network have productivity that is roughly 37 percent higher than indigenous-African firms. Education of managers is found to play only a modest role in determining productivity. Firms that have managers with secondary 
Table 6: Determinants of Productivity: regression results

\begin{tabular}{|c|c|c|c|}
\hline & Model 1 & Model II & Model III \\
\hline Intercept & $\begin{array}{l}6.12^{* * *} \\
(0.30)\end{array}$ & $\begin{array}{l}6.03^{* * *} \\
(0.31)\end{array}$ & $\begin{array}{l}5.88^{* * *} \\
(0.39)\end{array}$ \\
\hline Log(cap) & $\begin{array}{l}0.20 * * * \\
(0.03)\end{array}$ & $\begin{array}{l}0.19 * * * \\
(0.03)\end{array}$ & $\begin{array}{l}0.18^{* * *} \\
(0.03)\end{array}$ \\
\hline Log(labor) & $\begin{array}{l}0.77^{* * * *} \\
(0.06)\end{array}$ & $\begin{array}{l}0.76^{* * * *} \\
(0.06)\end{array}$ & $\begin{array}{l}0.73^{* * * *} \\
(0.06)\end{array}$ \\
\hline Capacity Utilization & $\begin{array}{l}0.006^{* * * *} \\
(0.002)\end{array}$ & $\begin{array}{l}0.005^{* * * *} \\
(0.002)\end{array}$ & $\begin{array}{l}0.005^{* * * *} \\
(0.002)\end{array}$ \\
\hline Secondary & & $\begin{array}{l}0.20^{*} \\
(0.12)\end{array}$ & $\begin{array}{l}0.21^{*} \\
(0.12)\end{array}$ \\
\hline University & & $\begin{array}{l}0.22 \\
(0.15)\end{array}$ & $\begin{array}{l}0.19 \\
(0.16)\end{array}$ \\
\hline Tech.Ed. & & $\begin{array}{l}0.07 \\
(0.13)\end{array}$ & $\begin{array}{l}0.05 \\
(0.13)\end{array}$ \\
\hline Trade Credit & & & $\begin{array}{l}0.42^{* * *} \\
(0.13)\end{array}$ \\
\hline $\begin{array}{l}\text { Years of relation with } \\
\text { supplier }\end{array}$ & & & $\begin{array}{l}0.01 * * \\
(0.006)\end{array}$ \\
\hline Asian network & $\begin{array}{l}0.37 * * * \\
(0.14)\end{array}$ & $\begin{array}{l}0.35^{* * *} \\
(0.14)\end{array}$ & $\begin{array}{l}0.28 * * \\
(0.14)\end{array}$ \\
\hline European network & $\begin{array}{l}0.51^{* * *} \\
(0.19)\end{array}$ & $\begin{array}{l}0.51^{* * *} \\
(0.19)\end{array}$ & $\begin{array}{l}0.38 * * \\
(0.19)\end{array}$ \\
\hline Food & $\begin{array}{l}0.28^{*} \\
(0.15)\end{array}$ & $\begin{array}{l}0.28 * \\
(0.15)\end{array}$ & $\begin{array}{l}0.35^{* * *} \\
(0.15)\end{array}$ \\
\hline Wood & $\begin{array}{l}-0.31 * * * \\
(0.13)\end{array}$ & $\begin{array}{l}-0.30 * * * \\
(0.13)\end{array}$ & $\begin{array}{l}-0.26^{* *} \\
(0.13)\end{array}$ \\
\hline Metal & $\begin{array}{l}0.08 \\
(0.08)\end{array}$ & $\begin{array}{l}0.09 \\
(0.15)\end{array}$ & $\begin{array}{l}0.13 \\
(0.14)\end{array}$ \\
\hline Kenya & $\begin{array}{l}-0.35 * * * \\
(0.16)\end{array}$ & $\begin{array}{l}-0.31 * * * \\
(0.18)\end{array}$ & $\begin{array}{l}-0.15 \\
(0.17)\end{array}$ \\
\hline Zambia & $\begin{array}{l}-0.20 \\
(0.16)\end{array}$ & $\begin{array}{l}-0.20 \\
(0.16)\end{array}$ & $\begin{array}{l}0.01 \\
(0.16)\end{array}$ \\
\hline Tanzania & $\begin{array}{l}-0.60 * * * \\
(0.17)\end{array}$ & $\begin{array}{l}-0.55^{* * *} \\
(0.17)\end{array}$ & $\begin{array}{l}-0.34^{* *} \\
(0.18)\end{array}$ \\
\hline Adj. Rsq & 0.73 & 0.74 & 0.74 \\
\hline $\mathbf{N}$ & 472 & 472 & 472 \\
\hline
\end{tabular}


education or have higher productivity than firms with managers that have only primary educations, or no formal education at all. But the returns to education do not increase significantly with additional qualifications, such as university education or a technical college degree. The inclusion of human capital in the equation does not affect the size or significance of the network coefficients. Access to supplier credit and length of supplier relationship, on the other hand, are both positive and significant determinants of productivity. After inclusion of financial control variables the network coefficients continue to be positive and significant, however, the magnitude and significance of these network coefficients both decline. The fact that network members continue to have higher productivity after controlling for access to supplier credit suggests that there are other advantages in belonging to the network besides gaining improved access to working capital.

\section{Networks and SME Growth}

Lastly, we look at the impact of networks on firm growth. Network externalities are hypothesized to influence firm growth by alleviating financial constraints, providing technical and market information, and governing contracts and relationships that allow member firms to take advantage of a wider range of economic opportunities.

Firm growth is defined as the logarithmic growth in employment between start-up and present. We look first at the impact of ethnic networks on growth, including only explanatory variables on firm size and age. As in the other stepwise regressions above, country and sector dummies are also included. We then augment the growth specification with human capital and financial characteristics to control for these variables.

Firm size and age are expected to be negatively related to growth, confirming Gibrat's Law and Jovanovic's learning model (Jovanovic 1982). According to Gibrat's Law and Jovanovic’s model, efficient firms prosper and inefficient firms fail. Entrepreneurs learn about their efficiency over time. This implies that smaller, younger firms should have higher and more variable growth rates than larger, older firms. It also 
implies that firm growth and variance are independent of size for firms of the same age. Many researches have tested Gibrat's Law and Jovanovic's learning model and found that growth and size are indeed negatively related (Hall 1987). Education of managers is expected to have a positive impact on growth, as more educated and experienced managers are hypothesized to be better managers and innovators and, as a consequence, more growth-oriented. Firms with stronger financial positions, represented by more numerous sources of startup finance, bank loans or informal loans, and collateralizable assets, such as title to its business property (proxy for the firm's access to finance), are also expected to grow faster.

The results of our model in table 7 show that firm age and size, as expected, are negatively related to growth. And, after controlling for these variables, networked firms are shown to grow faster than other firms. SMEs in the Asian network grow roughly 9 percent faster than indigenous-African firms. Education is found to be significant in determining firm growth. Managers with secondary and university educations run SMEs that grow 6 percent faster on average than SMEs with managers attaining primary or no education. But differences in rates of growth between networked firms and others cannot be explained by better education of the entrepreneurs managing networked firms. The significance and magnitude of the network effect does not change when controls for education are included. Finally, the regressions find that access to finance also matters for growth: firms that have collateralizable assets and access to formal finance grow faster than others. Controlling for finance, however, does not affect the level of significance or the magnitude of the network coefficients. Hence, network externalities are shown to make an important contribution to firm growth even after controlling for other factors, such as size and age of the firm and the entrepreneur's human capital and access to finance. 
Table 7: Determinants of Firm Growth: regression results

\begin{tabular}{|c|c|c|c|}
\hline & Model 1 & Model II & Model III \\
\hline Intercept & $\begin{array}{l}0.48 * * * \\
(0.04)\end{array}$ & $\begin{array}{l}0.42 * * * \\
(0.04)\end{array}$ & $\begin{array}{l}0.44^{* * * *} \\
(0.04)\end{array}$ \\
\hline Log(empt at start) & $\begin{array}{l}-0.096 * * * \\
(0.009)\end{array}$ & $\begin{array}{l}-0.05^{* * *} \\
(0.009)\end{array}$ & $\begin{array}{l}-0.07^{* * * *} \\
(0.01)\end{array}$ \\
\hline Log(firm age) & $\begin{array}{l}-.011 * * * \\
(0.01)\end{array}$ & $\begin{array}{l}-0.11^{* * *} \\
(0.01)\end{array}$ & $\begin{array}{l}-0.12^{* * *} \\
(0.01)\end{array}$ \\
\hline Secondary & & $\begin{array}{l}0.06 * * * \\
(0.03)\end{array}$ & $\begin{array}{l}0.05^{* * *} \\
(0.03)\end{array}$ \\
\hline University & & $\begin{array}{l}0.06 * * \\
(0.03)\end{array}$ & $\begin{array}{l}0.05^{*} \\
(0.03)\end{array}$ \\
\hline Tech.Ed. & & $\begin{array}{l}0.04 \\
(0.03)\end{array}$ & $\begin{array}{l}0.03 \\
(0.03)\end{array}$ \\
\hline Informal Loan & & & $\begin{array}{l}-0.05 \\
(0.04)\end{array}$ \\
\hline Bank Loan & & & $\begin{array}{l}0.06^{*} \\
(0.03)\end{array}$ \\
\hline Title & & & $\begin{array}{l}0.05^{* *} \\
(0.02)\end{array}$ \\
\hline Asian network & $\begin{array}{l}0.09 * * * \\
(0.03)\end{array}$ & $\begin{array}{l}0.08 * * * \\
(0.03)\end{array}$ & $\begin{array}{l}0.07^{* * *} \\
(0.03)\end{array}$ \\
\hline European network & $\begin{array}{l}0.13^{* * *} \\
(0.04)\end{array}$ & $\begin{array}{l}0.12 * * * \\
(0.04)\end{array}$ & $\begin{array}{l}0.12^{* * *} \\
(0.04)\end{array}$ \\
\hline Food & $\begin{array}{l}-0.04 \\
(0.03)\end{array}$ & $\begin{array}{l}-0.05 \\
(0.03)\end{array}$ & $\begin{array}{l}-0.05^{*} \\
(0.03)\end{array}$ \\
\hline Wood & $\begin{array}{l}-0.02 \\
(0.03)\end{array}$ & $\begin{array}{l}-0.01 \\
(0.03)\end{array}$ & $\begin{array}{l}-0.02 \\
(0.02)\end{array}$ \\
\hline Metal & $\begin{array}{l}-0.02 \\
(0.03)\end{array}$ & $\begin{array}{l}-0.02 \\
(0.03)\end{array}$ & $\begin{array}{l}-0.02 \\
(0.03)\end{array}$ \\
\hline Kenya & $\begin{array}{l}-0.05 \\
(0.03)\end{array}$ & $\begin{array}{l}-0.02 \\
(0.03)\end{array}$ & $\begin{array}{l}-0.03 \\
(0.03)\end{array}$ \\
\hline Zambia & $\begin{array}{l}-0.03 \\
(0.03)\end{array}$ & $\begin{array}{l}-0.02 \\
(0.03)\end{array}$ & $\begin{array}{l}-0.03 \\
(0.03)\end{array}$ \\
\hline Tanzania & $\begin{array}{l}-0.03 \\
(0.04)\end{array}$ & $\begin{array}{l}0.01 \\
(0.04)\end{array}$ & $\begin{array}{l}0.01 \\
(0.04)\end{array}$ \\
\hline Adj. Rsq & 0.23 & 0.24 & 0.25 \\
\hline $\mathbf{N}$ & 472 & 472 & 472 \\
\hline
\end{tabular}




\section{Negative Network Effects}

Stable and cohesive business networks help member firms enter at larger size and perform better in SSA, but they can have some undesirable side effects on equity, market efficiency, and competition, and they may work to deny footing to later development of more appropriate institutions. (North 1990; Bardhan 2005; Fafchamps 2004). The central problem is that, while network "insiders” gain advantages from network externalities, non-member "outsiders" can be excluded from essential business transactions - as in the case of access to supplier credit discussed at the end of this section.

There are accumulated costs in building trust among network members and because of these sunk costs, members find it easier to deal with each other than to incur the added costs of screening new business partners. "Outsiders” are therefore excluded from many business transactions. "Outsiders” are also problematic where "insiders" have a minority status. Members of important minority ethic networks in SSA, like the IndianAsians in East Africa or the Lebanese in West Africa, find it exceedingly difficult to enforce contracts against indigenous-African businesses in a setting where there is great potential for ethnic conflict and minorities have limited political leverage. Taken together, the features of African networks - network externalities, restricted entry, minority status, and sunk transaction costs - produce a kind of "lock-in:” rather stable business networks and rather static patterns of business exchange. Lock-in is reinforced by economic conditions in many SSA countries. In slow growing, poor economies, where business activity is mainly based on primary products and simple manufacturing, there is little innovative activity to shake things up and opportunities for gains from trade are relatively stable over time. Plateau (2000) also finds that low density of population and businesses reinforces adverse effects of networks (monopoly, exclusiveness) and high density is conduce to the emergence of better networks and institutions. Lastly, economic malaise, brought on by failed economic policies in many African countries, has meant fewer avenues open for economic advancement, and this has encouraged attempts to seek wealth by trading on ethnic connections (Bardhan 2005). 
In this atmosphere, new firm formation and investment are challenging for entrepreneurs that are not members of existing networks. Connections matter for access to financial resources, quality inputs, skilled labor, and information on technology and markets. Network "insiders" have better access to these productive resources and therefore have larger size at entry, higher productivity and faster growth rates, as we have shown. Relationships also matter for entering certain business activities. New entrants have to deal with established market participants and create new business relationships. Some way has to be found to establish trust-based relationships and to enforce contracts. New investors with contacts in these business activities, because of referrals from other network "insiders" or relatives, have a distinct advantage. As a consequence, entrepreneurs in SSA are inclined to enter businesses where they are known and connected. ${ }^{9}$

Ultimately, patterns of network specialization are established in specific activities, and information sharing, referrals, and existing relationships cause these patterns to persist over time. Distinct patterns of ethnic concentration in particular businesses are quite evident in the RPED enterprise data (Biggs and Srivastava 1996; Bigsten et al 2000). This zoning of economic activity by business networks has distributional consequences. Networks controlling highly profitable activities do better, and the resulting differentials in income that arise between groups can persist. Non-members of the network are in effect excluded from many opportunities. Exclusion and the persistence of income differences can lead to conflict, reduced investment, and capital flight.

Partition of economic activity by networks also influences the allocative efficiency of financial and human capital. Where business activities are controlled by

\footnotetext{
${ }^{9}$ This has some similarities with what studies find in more developed countries. Entrepreneurs tend to start up businesses in industries where they have "experience" (Audretsch 1995). Experience implies connections, as they are similarly useful in advanced countries for learning and getting access to resources and markets. But in developed countries, where there are strong market institutions and more generalized trust, experience relates more to industry-specific technical knowledge and customer connections.

Technical experience and customer knowledge are important in Africa too, as indicated in our regressions on determinants of size at start up and firm performance. But the argument here is that, in the presence of weak or missing market institutions and high transaction costs, connections are essential. Without them entry and survival are highly problematical, as firms will have difficulties getting access to credit and inputs, as well as enforcing contracts.
} 
different networks, investment capital is constrained in seeking the highest returns. Network members are compelled by virtue of their contacts to invest in particular businesses and “outsiders” are reluctant to invest in these areas. Human capital formation can be effected too because the zoning of economic activity raises expected returns from human capital investments in economic activities where one has connections and lowers them in activities where one lacks connections. Absent public institutions to ensure more generalized trust, young talent will tend to make career choices based on where they can expect to earn the highest returns, which is a function of connections. In the same way, this prevailing connections-based reward structure can distort the allocation of scarce entrepreneurial resources, reducing innovation and new firm formation in potentially important areas of comparative advantage. Hence, the aggregate efficiency cost of the partition of economic activity by networks can be high.

Finally, the anti-competitive effects of the zoning of economic activity by networks can be substantial. Control of certain business activities by particular networks restricts entry and drives up profits for the incumbent network. Competitors face entry barriers because of high costs of building relation-based governance systems necessary to do business in these activities and the lack of connections that could reduce such costs. As a result, excess profits and the rents to network externalities persist. This can be true of whole industries, as well as profitable segments along the value chain of particular industry segments. Consequently, when all the adverse effects of tight networks in the SSA environment are considered, the costs can be high.

\section{An Example of Negative Network Effects}

Differential access to supplier credit provides a good example of negative network effects. The extent to which network members actually rely on the network to obtain information about the trustworthiness of potential borrowers and to enforce contracts is difficult to measure directly. It is also difficult to assess the degree to which non-members of the network are excluded from exchange. Supplier credit outcomes can be used as a measure of both of these effects in the face of market and government failures. 
The willingness of suppliers to extend credit to their customers, according to RPED survey respondents, depends on the risk of nonpayment (Biggs and Srivastava 1996). Given the inadequacy of courts, risk of nonpayment depends on the amount of information suppliers have about customers and the ability to enforce the contract informally. Thus, a customer looking for credit has to establish a trust-based relationship with the supplier either by way of long-term repeat interactions or by way of connections. Public information about credit histories of firms, which could alleviate some of the concerns about information and enforcement problems, is unavailable in most African countries, and financial institutions and other firms are generally unwilling to share this type of information because it is a source of rents. So firms must establish a relationship with each potential source of supplier credit, as we discussed earlier.

Networks overcome many of these problems by sharing information about credit histories within the group and enforcing contracts within the group. But the consequences of these network externalities are that non-members are left to the long process of getting credit via repeated interaction or not getting supplier credit at all.

As upstream industries in many SSA countries are controlled by minority ethnic networks, it is the downstream small and medium indigenous-African producers that are excluded by network effects in most cases. They have few connections to these minority communities and no equivalent multilateral reputation mechanism that facilitates the sharing of credit histories and enforcement. Minority ethnic suppliers also find it hard to differentiate between indigenous-African firms, as their payment records do not travel across ethnic boundaries. Indigenous-African SMEs are therefore subjected to statistical discrimination: they are all placed in the same high risk category by upstream suppliers. In addition, as we noted above, minority suppliers are apprehensive about enforcing contracts in the indigenous-African community because of political concerns. They also know that when the time comes to make the inevitable decisions about contract flexibility, it will be difficult for them to get enough information on indigenous-African firms to sort out late payers with legitimate business problems from late payers just being opportunistic. 
Table 8 presents the results of an analysis of the probability of receiving supplier credit in our four countries. We begin by estimating a probit regression to look at the effects of networks on access to credit. We then examine the determinants of access to supplier credit for networked SMEs and indigenous-African SMEs separately.

The role of the network in facilitating access to credit is considered in model I, where firm size (log empt) is included to control for the fact that larger firms have better access to credit. The results show that networked SMEs are much more likely to receive supplier credit than indigenous-African SMEs. As expected, the coefficient on firm-size is positive and significant, indicating that larger firms are more likely to get supplier credit than smaller firms. These findings confirm those of other researchers using the RPED data who have noted an ethnic bias in supplier credit access in SSA. (Biggs, Raturi and Srivastava 2002; Fisman 2002; Fafchamps 2004). ${ }^{10}$

Adding the length of relationship with the supplier (log yrssrel) to the probit in model II, we see that the number of years a firm has known its supplier is significant in determining access to supplier credit. This validates the notion that information gained from repeated interactions plays an important role in the willingness of suppliers to extend credit. However, the fact that the network coefficients change only marginally in this regression indicates that the information provided by repeated interactions and firmsize is not enough to explain credit access. SMEs in networks are still much more likely to receive supplier credit than indigenous-African SMEs because of network externalities. ${ }^{11}$

\footnotetext{
${ }^{10}$ Fafchamps (2004) also analyzed financial case study data from about 40 firms and suppliers, collected by RPED teams in Zimbabwe and Kenya as part of the survey work in those countries. He tries to explain why ethnic networks matter so much in getting access to supplier credit by using a "socialization" variable in his regressions, which measures the degree of networking among "insiders." Although the sample is quite small and the data are noisy, he tentatively finds that the network effect (socialization) is important, but ethnicity on its own still remains an important part of the ethnic impact on access to credit after controlling for networking. He argues that the remainder of the effect might simply be statistical discrimination or other factors.

${ }^{11}$ Fisman (2002) finds in some of the RPED countries that firms are about twice as likely to obtain credit from suppliers from within their own ethnic community than from outsiders.
} 
The advantages of the network are made even clearer by examining the determinants of access to supplier credit in the two groups of firms separately. The analysis in models III and IV shows that, for SMEs in networks, the only determinant of access to supplier credit is firm size, and the magnitude of its importance is much smaller than for indigenous-African firms. This suggests two things. First, networked SMEs do not have to rely on establishing long-term relationships with suppliers to get credit, as their reputation in the network provides enough information to lenders. Second, even new firms in the network get access to supplier credit.

Table 8: Probability of Receiving Supplier Credit

Probit regression results

\begin{tabular}{|c|c|c|c|c|}
\hline & Model I & Model II & $\begin{array}{l}\text { Model III } \\
\text { (Network) }\end{array}$ & $\begin{array}{l}\text { Model IV } \\
\text { (Africans) }\end{array}$ \\
\hline Constant & $\begin{array}{c}-2.1^{* * * *} \\
(0.23)\end{array}$ & $\begin{array}{l}-2.3^{* * *} \\
(0.23)\end{array}$ & $\begin{array}{c}-1.07 * * * \\
(0.36)\end{array}$ & $\begin{array}{c}-2.9 * * * \\
(0.38)\end{array}$ \\
\hline Log(empt) & $\begin{array}{c}0.41^{* * *} \\
(0.06)\end{array}$ & $\begin{array}{c}0.40 * * * \\
(0.05)\end{array}$ & $\begin{array}{c}0.25^{* * *} \\
(0.07)\end{array}$ & $\begin{array}{c}0.56^{* * *} \\
(0.09)\end{array}$ \\
\hline Log(yrssrel) & & $\begin{array}{l}0.13 * * \\
(0.06)\end{array}$ & $\begin{array}{c}0.07 \\
(0.08)\end{array}$ & $\begin{array}{l}0.17^{*} \\
(0.10)\end{array}$ \\
\hline Asian network & $\begin{array}{c}0.44^{* * *} \\
(0.17)\end{array}$ & $\begin{array}{l}0.41 * * \\
(0.16)\end{array}$ & & \\
\hline European network & $\begin{array}{c}0.54 * * * \\
(0.21)\end{array}$ & $\begin{array}{c}0.49 * * * \\
(0.21)\end{array}$ & & \\
\hline Food & $\begin{array}{l}-0.59 * * * \\
(0.19)\end{array}$ & $\begin{array}{c}-0.59 * * * \\
(0.19)\end{array}$ & $\begin{array}{c}-0.84 * * * \\
(0.24)\end{array}$ & $\begin{array}{l}-0.41 \\
(0.36)\end{array}$ \\
\hline Wood & $\begin{array}{l}-0.28 \\
(0.18)\end{array}$ & $\begin{array}{c}-0.26 \\
(0.18)\end{array}$ & $\begin{array}{c}-0.43^{* *} \\
(0.24)\end{array}$ & $\begin{array}{l}-0.10 \\
(0.30)\end{array}$ \\
\hline Metal & $\begin{array}{l}-0.07 \\
(0.20)\end{array}$ & $\begin{array}{l}-0.05 \\
(0.20)\end{array}$ & $\begin{array}{l}-0.21 \\
(0.26)\end{array}$ & $\begin{array}{c}0.07 \\
(0.32)\end{array}$ \\
\hline Kenya & $\begin{array}{l}0.28^{*} \\
(0.16)\end{array}$ & $\begin{array}{l}0.27^{*} \\
(0.16)\end{array}$ & $\begin{array}{c}0.20 \\
(0.20)\end{array}$ & $\begin{array}{c}0.57^{* *} \\
(0.28)\end{array}$ \\
\hline Zimbabwe & $\begin{array}{c}1.28 * * * \\
(0.18)\end{array}$ & $\begin{array}{c}1.25^{* * *} \\
(0.18)\end{array}$ & $\begin{array}{c}1.68^{* * *} \\
(0.25)\end{array}$ & $\begin{array}{c}1.00 * * * \\
(0.29)\end{array}$ \\
\hline LLr & -244.7 & -244.6 & -145.3 & -87.3 \\
\hline $\mathbf{N}$ & 555 & 555 & 304 & 251 \\
\hline
\end{tabular}


For indigenous-African SMEs, firm size and length of relationship with supplier are both shown to be important determinants of access to supplier credit. As we noted above, many of the upstream supplier industries in SSA are controlled by ethnic minority firms and they extend the lion's share of supplier credit. In the absence of good information on indigenous-African firms, these suppliers use firm-size as a proxy for information and enforcement capability and for the value of the relationship. Thus, only large indigenousAfrican firms get supplier credit without difficulty. For members of the ethnic network, suppliers have relatively good information on their businesses and their social connections and firm-size is less useful (although the regressions show it still matters to some degree). The end result is indigenous-African SMEs are treated as "outsiders" and are left to establishing long-term relationships with each supplier to get access to supplier credit.

We calculated the predicted probabilities of receiving supplier credit for networked SMEs and indigenous-African SMEs, using model IV in table 8. For the average-sized indigenous-African firm (9 employees), which had a four year relationship with its supplier, the likelihood of receiving credit was only 7 percent in Zambia (table 9). In Kenya and Zimbabwe, the chances of this non-networked firm receiving credit were higher, 18 percent and 32 percent respectively, reflecting differences across these countries, among other things, in the development of manufacturing, sophistication of firms, development of formal institutions, and depth of financial systems. However, across all the countries, the probabilities of receiving supplier credit for a given firm size are much higher for SMEs in ethnic networks. An average-sized networked firm in Zambia, for example, has four times the probability (29 percent) of receiving supplier credit than an indigenous-African firm (table 10). Also, the influence of size on the probability of receiving credit is much greater for indigenous-African firms than for networked SMEs. In Zambia, for example, one standard deviation higher mean size (micro to small) for indigenous-African firms increases the probability of receiving credit from 7 percent to 14 percent, a 100 percent increase. For networked SMEs, one standard deviation higher mean size in Zambia raises the probability of receiving credit from 29 percent to 35 percent, a 21 percent increase. 
The predicted probabilities of receiving credit also indicate that length of relationship is a significant determinant of credit access for indigenous-African SMEs. Across average firm size classes and across countries increases in length of relationship with supplier raise the chances of receiving supplier credit for indigenous-African firms. A micro-enterprise in Zambia, which has a ten year established relationship with its supplier (one standard deviation higher than the mean) has a 9\% chance of receiving credit, an increase of $28 \%$. The probability of receiving supplier credit for networked SMEs, on the other hand, is unaffected by length of relationship with supplier, as we noted above.

Table 9: Probability of Receiving Supplier Credit for Indigenous-African Firms

(Evaluated at various levels of enterprise size and length of supplier relationship)

\begin{tabular}{llll}
\hline & Zambia & Kenya & Zimbabwe \\
\hline $\begin{array}{l}\text { Micro firm, 4 years } \\
\text { relation with supplier }\end{array}$ & 0.07 & 0.18 & 0.32 \\
$\begin{array}{l}\text { Micro firm, 10 years } \\
\text { relation }\end{array}$ & 0.09 & 0.23 & 0.38 \\
$\begin{array}{l}\text { Small firm, 4 years } \\
\text { relation with supplier }\end{array}$ & 0.14 & 0.30 & 0.47 \\
$\begin{array}{l}\text { Small firm, 10 years } \\
\text { relation with supplier }\end{array}$ & 0.18 & 0.36 & 0.53 \\
\hline
\end{tabular}

Table 10: Probability of Receiving Supplier credit for Networked SMEs

(Evaluated at various size classes)

\begin{tabular}{lccc}
\hline & Zambia & Kenya & Zimbabwe \\
\hline Micro firm & 0.29 & 0.36 & 0.85 \\
Small firm & 0.35 & 0.43 & 0.89 \\
\hline
\end{tabular}


To recap the main points of the paper before we move on to the implications for policy, SSA has an extremely difficult contracting environment. SMEs respond to this poor environment by creating architectures of relation-based governance that substitute for missing market-supporting institutions. In the shock-prone business climate of the region, however, it is hard in some cases to create and sustain cooperative, self-enforcing relationships, because economic instability can undermine repeated game incentives. Tight, ethnically-based networks emerge and thrive in this setting, as there is an added need for the information and collectivist system of enforcement that a network can provide to help make and sustain relational contracts. The RPED surveys show that there is a coordination failure in the indigenous-African manufacturing business community that keeps firms from developing an effective multilateral reputation mechanism analogous to that found in ethnic minority networks. We show that the social capital in minority ethnic networks confer major benefits on member firms, facilitating larger size at entry, higher productivity, and faster growth. But there are features of these networks that can produce a kind of "lock-in:” stable networks and static patterns of business exchange. Lock-in is reinforced by the economic conditions and sparse business environments in SSA. Stable and cohesive, ethnically-based networks can have adverse consequences for income distribution, resource allocation, and competition. “Outsiders” can be excluded from supplier credit and many other business transactions. Adverse network effects fall hardest on indigenous-African firms.

\section{Implications for Institutions and Policies in SSA}

We are now in a better position to address the questions posed at the beginning of this paper. Do interventions to assist SMEs in developing private institutional support arrangements make sense for countries in Sub-Saharan Africa? And, if interventions are required, what types of policies or programs might be needed?

We have shown that African SMEs lacking access to formal institutions and facing market failures and high transaction costs have been able to engage in a range of productive activities and gain access to needed working capital by creating workable private institutional arrangements to govern these transactions. We have also shown that 
there are important links between these informal governance institutions and SME performance. It is clear that such relation-based governance mechanisms will be important for some time to come in SSA, as it will take time to develop modern formal institutions to foster more generalized trust and replace informal governance systems in the region. In the interim, a prudent strategy for institutional development to support more market exchange would seem to be twofold: make the environment as supportive as possible for relation-based governance and work to build on such private institutional arrangements to improve their performance, where feasible.

Achieving this strategy will require interventions in several areas. First, the business environment in SSA, as we noted, has features that work to undermine and weaken incentives for cooperation and inter-firm relational contracting, limiting the ability of firms to create and sustain efficient architectures. Policy reform is needed to create a better environment for relation-based governance. Second, tight, ethnicallybased networks, which have arisen as part of systems of relation-based governance, can create adverse (exclusionary) effects for indigenous-African SMEs. Interventions may be needed in some countries to mitigate these adverse network effects. Third, self-help substitutes for missing marketing-supporting institutions can go only so far without the development of other formal institutions to foster a progressive transition from personal to more anonymous exchange. A cumulative program of building higher quality institutions will be needed to enforce property rights and contracts and reduce uncertainties and transaction costs. Each of these rationales for government assistance is discussed in turn below together with suggestions for policy and programs.

Creating a better environment for relation-based governance: A number of theoretical and empirical studies suggest that a country does not need a lot of formal institutional capacity to achieve a semi-industrial level of income (Rodrik 2003; Dixit 2004). As Dixit (2004, p.151) argues, in early stages of development, when economic activity is on a small scale, trade is localized, and economic transactions involve a relatively small group of people, self-enforcing governance is feasible. Elaborate state institutions are not 
needed. Some basic protection of property rights is helpful, but even that may be achievable privately or using social norms and sanctions. Even a corrupt state can permit reasonably efficient outcomes, if it has sufficient stability. The lessons from East Asia lend support to this view. Many important economic transactions in these fast-growing countries were relation-based rather than rule-based in the formative stages of industrial transformation in these countries, demonstrating that one can go a long way on relationbased governance systems (Bardhan, 2005).

Consequently, it is essential that governments in SSA aim first to establish a stable platform for inter-firm cooperation and relation-based governance of market exchange. Where economic and political instability are high, establishing informal trading relationships is much harder and market exchange is forced to be highly personalized and localized, limiting potential gains from specialization and division of labor. A priority for government should be to reduce instability through better economic management and governance. Unstable macro-economic conditions, resulting in part from poor policy management, frequent policy changes, and governance problems, are an important cause of instability in the African business climate.

Addressing undesirable network effects: Networks in SSA generate positive externalities and improve the possibilities for market exchange. But they also can have unwanted side effects. Network externalities and statistical discrimination exclude many SMEs from credit and from normal commercial practices. Policies to address this problem should aim at two areas (a) expanding the limits of network boundaries to allow more transactions with “outsiders” and (b) mitigating the exclusionary effects of networks on disadvantaged firms.

”Linkage programs” and “cluster development initiatives” could be important in underwriting some of the costs of building trust between networked firms and “outsiders.” As we noted earlier, there are accumulated costs in building trust among network members and because of these sunk costs, members find it easier to deal with each other than to incur the added costs of screening new business partners. Subsidizing some of the costs of bringing firms together in various types of relationships or clusters 
may be beneficial in expanding the boundaries of networks and reducing the adverse effects of lock-in. Beyond this, broader efforts to help link-up SMEs, particularly indigenous-African firms, with foreign investors and larger indigenous enterprises, as potential suppliers, could help to compensate for some of the exclusionary effects and monopoly power of existing networks.

Effective implementation of such programs, however, will generally require more than just introducing firms to each other. Building trust takes time and may call for efforts to build the capability of excluded firms. Fisman (2002) finds, for example, that preferential access of network members to supplier credit and inputs in some RPED countries does not just result from network information and enforcement externalities, but can also be attributed to differences in observable firm and owner quality - a skills component. Hence, bringing about improvements in firm quality that would allow indigenous-African businesses to compete more generally may also be an effective means of improving access to the network. Education and training directed at indigenousAfrican firms might substitute for the skills component that appears to be responsible for some of the greater credit access among ethnic businesses.

Private for-profit provision of information and enforcement may also have some merit in expanding network boundaries. For example, establishing credit rating agencies could help to improve access to supplier credit for SMEs with decent credit histories. Circulating information about credit repayment histories could assist suppliers in screening unreliable business partners and increase the chances of reliable firms in getting credit. While they take time to develop, credit bureaus might also help firms that have insufficient collateral qualify for credit from financial institutions offering bills discounting and short-term working capital loans. Efficient private enforcement services, such as repossession firms and the like, might have similar effects. However, as Dixit (2004) argues, private enforcement, unlike private provision of information, can often be problematic, as a private enforcer can create the demand for his own services and extort more from society than any benefits he provides. 
Finally, "lock-in," in terms of stable business networks and static patterns of business exchange, is reinforced by economic conditions in many SSA countries, as we noted earlier. Hence, policy reform efforts that reduce restrictions and regulatory barriers on market development and shake things up by improving conditions for innovative activity and investment can help to weaken the hold of tight ethnic networks. Bardhan (2005) notes that expanding markets and profit opportunities give salience to incentives at the individual level and thus undermine the hold of ethnic networks. As markets develop, particularly for credit, insurance, and information, dependence on ethnic networks for these essential functions declines. By improving outside opportunities and exit options for network members, markets reduce the effectiveness of social sanctions and cohesiveness, devaluing networking and exclusiveness.

Policies to mitigate exclusionary effects of ethnic networks on disadvantaged firms could also consider preferences aimed at indigenous-African SMEs. Many developing countries have created programs to provide preferential treatment to disadvantaged groups in jobs, investments, finance, business contracts and so on. Variants of this form of intervention have been introduced in Malaysia, Indonesia, India, Philippines, Nigeria, and elsewhere. Such policies have had short-run positive effects on fostering more inclusion and development of the disadvantaged in some countries, however, they have generally been costly in the longer run.

On the positive side, when peer effects and role models are important determinants of economic success in a country, preferences for excluded groups can increase efficiency by changing the way labor and entrepreneurial talent or finance is allocated across occupations and investment opportunities. Also, to the extent that statistical discrimination by way of negative-stereotypes about the capability and trustworthiness of excluded groups plays a role in access to finance or business contracts, preferential loans or programs to tilt the allocation of government contracts for some length of time may help in eliminating such stereotypes. Finally, in the manner of infant industry protection, preferences can offer temporary protection against competition to excluded firms, providing them space to learn-by-doing and catch up with others. Many of these factors played a role, for example, in the early successes of Malaysia's New 
Economic Policy, which extended preferences to bumiputera or pribumi (see article in The Economist 8/27/05).

But, on the negative side, if continued for too long, preferences can end up being a disincentive to learning and efficient resource allocation. Over time these policies have generally resulted in substantial rent seeking and "infants" that have refused to grow up. Also, preference policies, once adopted, have been difficult to remove. In the end, Malaysia’s New Economic Policy and Nigeria's Indigenization Program and others remained for too long and resulted in a substantial transfer of rents to the politically wellconnected (for Nigeria see Biersteker 1984).

Strengthening formal institutions to promote the transition from personal to more anonymous exchange: Reliance on informal, private mechanisms to govern contracting and market exchange has limits even in the best of cases. The need for more sophisticated forms of formal institutions increases as the market widens and the scope for opportunism grows. More complex formal institutions must evolve to enforce property rights and contracts, to reduce uncertainties and transaction costs, and to allow the productivity gains from increasing scale and improved technology to be realized. Many of these institutional structures are nonexistent, weak, poorly designed, or poorly managed in SSA as we detailed earlier. Governments in the region are also sometimes too weak to act as a guarantor of these rights and institutions or are much too predatory in their own demands and pose a threat to them.

What is becoming clear in the theoretical and empirical research on institutional development, however, is that it is not always necessary or prudent to try to move directly to building a set of formal Western-style legal institutions to solve these problems (Rodrik 2003; Dixit 2004). A cumulative process of building higher quality local institutions, working with available informal institutions where feasible, may be a better alternative. The history of most developing countries is a story of sequential development of more complex institutions and organizations appropriate for the governance of market exchange and investment at particular stages of their development. Strategies to strengthen formal institutions should consider moving away from a focus on 
"best practice" models and shift more attention toward context-specific analysis of effective institutional arrangements (including private orderings) that can assist in the transition form personal to more anonymous exchange. 


\section{References}

Alchian, A and Demsetz, H. (1972), "Productivity, Information Costs, and Economic Organization,” AER, 62, 777-95.

Audretsch, D. (1995), Innovation and Industry Evolution. Cambridge, Mass: MIT Press.

Axelrod, R. (1984), The Evolution of Cooperation. New York: Basic Books.

Bardhan, P. (2005), Scarcity, Conflicts, and Cooperation: Essays in the Political and Institutional Economics of Development. Cambridge, Mass: MIT Press.

Barr, A. (2000), "Social capital and technical information flows in the Ghanaian manufacturing sector,” Oxford Economic Papers 52(3): 539-59.

Barr, A. (1998) "Enterprise Performance and the Functional Diversity of Social Capital," Working Paper, Center for the Study of African Economies, Oxford University.

Becattini, G. (1990), “The Marshallian Industrial District as a Socio-economic Notion,” in Pike et al. Industrial Districts and Inter-Firm Cooperation in Italy, ILO, Geneva.

Bernstein, L. (1992), “Opting Out of the Legal System: Extralegal Contractual Relations in the Diamond Industry.” Journal of Legal Studies 21.

Biersteker, T. (1984), Multinationals, The State, and Control of the Nigerian Economy. Princeton University Press.

Biggs, T. Raturi, M. and Srivastava, P. (2002), "Ethnic Networks and Access to Credit: Evidence from the Manufacturing Sector in Kenya,” Journal of Economic Behavior and Organization vol. 1435, 1-14.

Biggs, T. and Srivastava, P. (1996) "Structural Aspects of Manufacturing in Sub-Saharan Africa: Findings from a Seven Country Enterprise Survey” World Bank Discussion Paper No\# 346 Africa Technical Department, World Bank, Washington, DC.

Biggs, T. and Shah, M. (2002) “The Problem of African Entrepreneurial Development” in Fields, G and Pfeffermann, G Pathways Out of Poverty, Kluwer Academic Publishers, Boston.

Bigsten, A, et al. (2000a) "Contract Flexibility and Dispute Resolution in African Manufacturing,” Journal of Development Studies 36 (4) 1-37.

Brusco, C. (1992), “The Idea of the Industrial District” in Pike et al. Industrial Districts and Inter-firm Cooperation in Italy, ILO, Geneva.

Coase, R. (1937) “The Nature of the Firm,” Economica 4: 386-405 
Coase, R. (1988) The Firm, the Market and the Law, University of Chicago Press.

Collier, P. and Gunning, J. (1999), “Explaining African Economic Performance,” Journal of Economic Literature, Volume XXXVIII.

Dixit, A. (2004) Lawlessness and Economics, Princeton University Press.

Fafchamps, M. (2000) “Ethnicity and Credit in African Manufacturing,” Journal of Development Economics 61(1): 205-35.

Fafchamps, M. (2004) Market Institutions in Sub-Saharan Africa. Cambridge, Mass: MIT press.

Fisman, Ray, (2001), "Trade Credit and productive Efficiency in Developing Economies,” World Development, 29 (2): 311-21.

Fisman, Ray, (2002), "Ethnic Ties and The Provision of Credit: Relationship-level Evidence from African Firms,” Mimeo.

Gambetta, D. (1988) Trust: Making and breaking Cooperative Relations. Basil Blackwell, New York.

Hall, B (1987), "Relationship between Firm Size and Firm Growth in the US Manufacturing sector,” Journal of Industrial Economics 35: 583-606.

Hart, K. (1988) "Kinship, contract, and trust: The economic organization of migrants in an African city slum,” In Trust: Making and Breaking Cooperative Relations, D.Gambetta (ed.) Basil Blackwell, New York.

Kay, J (1993) Foundations of Corporate Success. Oxford University Press

Kranton, R.E. (1996) “The formation of cooperative relationships,” Journal of Law, Economics and Organizations 12(1): 214-33.

McMillan, J., and Woodruff, C. (1999) "Interfirm Relationships and Informal Credit in Vietnam,” Quarterly Journal of Economics 114(4): 1285-1320

Mc.Millan, J. and Woodruff, C. (2003) "The Central Role of Entrepreneurs in Transition Economies," in Fields, G and Pfeffermann, G Pathways Out of Poverty, Kluwer Academic Publishers, Boston.

North, D. (1990), Institutions, Institutional Change, and Economic Performance. New York : Cambridge University Press.

Piore, M and Sabel, C (1984), The Second Industrial Divide, Basic Books.

Plateau, J-P. (2000), Institutions, Social Norms, and Economic Development. London: Routledge. 
Porter, M (1990) The Competitive Advantage of Nations, Mcmillan.

Rodrik, D. (2003), In Search of Prosperity: Analytical Narratives on Economic Growth. Princeton University Press.

The Economist. (8/27/05), “Failing to Spread the Wealth,” Volume 376, Number 8441.

Thompson, G et. al, (1991), Markets, Hierarchies and Networks: The Coordination of Social Life, Open University Press.

Williamson, (1985) The Economic Institutions of Capitalism: Firms, Markets and Relational Contracting, The Free Press. 